\title{
STUDENTS' UNDERSTANDING THROUGH THE USE OF ICT-BASED ACCOUNTING MULTIMEDIA (MAKSI) IN VOCATIONAL HIGH SCHOOLS
}

\author{
Vivi Pratiwi \\ Sebelas Maret University \\ vivipratiwi25@gmail.com \\ Siswandari \\ Sebelas Maret University \\ siswandari@staff.uns.ac.id \\ Djoko Santosa \\ Sebelas Maret University \\ djoko.santosa@gmail.com
}

\begin{abstract}
This study aims to describe the use of MAKSI: Information and Communication Technology (ICT) based accounting multimedia in improving students' understanding on bank reconciliation material in Vocational High Schools (SMK). This research is a quantitative-descriptive research with case study method involving 40 students. Data collection techniques used are tests using essay tests, observations and interviews. The result showed that the average understanding before using MAKSI is 52.18 with the less category, while after using MAKSI the average increases to 76.23 with good category. Before using MAKSI, $65 \%$ of students have less understanding, $27.5 \%$ have sufficient understanding, while 10\% have good understanding. After using MAKSI, the percentage of the the students who have good understanding increases to 40\%. In addition, there are $40 \%$ of students who have very good understanding. Those who have less understanding are only $7.5 \%$ while $12.5 \%$ of them have sufficient understanding. Thus, the use of MAKSI in learning in SMK can improve students' understanding.
\end{abstract}

Keywords: learning media, ICT, multimedia, understanding, accounting, SMK. 


\section{INTRODUCTION}

Learning is the most important activity in the process of developing student potential and character. It is an activity to explore knowledge, as part of the initial development of knowledge literacy and is perfected through practice in the field (Cajkler \& Wood, 2016, p. 98). In order for learning activities to run according to purpose, then learning activity should be designed as attractively as possible. Interesting learning activities can be done by giving students real-life illustrations, showing empathy to their difficulties, being enthusiastic in teaching, explaining interestingly, and establishing continuous knowledge concepts between curriculum, teachers, and students (Butler \& Reddy, 2010, p. 776). This can be done by providing the relevant tasks with the ability, skills, and abilities of students can apply it daily.

Teachers should be able to adjust the learning conditions that students can use thoroughly because students have different learning behaviors. The adjust of conditions in question is the application of strategies, models, or learning methods that will be done in the learning process. Lesson planning also needs to be done for effective learning so as to encourage students to reflect on knowledge, skills, and attitudes to new problems encountered (Scott \& Cong, 2010, p. 283). Learning needs to be conditioned in such a way as to actual conditions so that students get a concrete, meaningful, and memorable experience (Sanjaya, 2013, p. 35). Someone is said to learn if there is a change of behavior either cognitive, affective, or psychomotor changes thoroughly (Dimyati \& Mudjiono, 2010, p. 10). Changes in student behavior that is the process of learning is visible through the behavior of students learning the material. Learning behavior is a student response to the action of learning from the teacher. Thus, the design of appropriate learning in accordance with the conditions and learning needs of students will facilitate the achievement of learning objectives. Students will also more easily understand the material so that student learning outcomes will increase.

Along with the development of the era, the success of learning depends on the accuracy of teachers in using technology to fit the learning objectives and specifically create meaningful learning for students (Wankel \& Blessinger, 2015, p. 5). Through these advancements teachers can use various media in accordance with the needs and objectives of learning. By using technology-based learning media not only can simplify and streamline the learning process, but also can create an interesting learning process, fun, memorable and provide a direct learning experience for students. Therefore, it is necessary to design a learning by using technology or Information, and Communication Technology (ICT) in order to maximize student learning activities. The use of ICT in learning is already a demand that must be met in the current era of learning because ICT is also proven to optimize student learning outcomes.

In general, ICT in education is considered a challenge and opportunity (Lindberg, Olofsson, \& Fransson, 2017, p. 129; Shittu \& Shittu, 2015, p. 180). ICT is perceived as a challenge due to the time constraints of learning and the lack of expertise in the use of ICT. On the other hand, ICT is considered an opportunity because of the strong expectations of teachers and students about the development of ICT utilization in education to facilitate ease of learning. Teachers as educators will always be required to be creative and innovative in seeking learning breakthrough in order to achieve learning objectives and be able to generate students' happiness during the learning process (Saputra \& Purnama, 2012, p. 61). This is because teachers play an important role in the development of attitudes, knowledge, and skills of students. Therefore, teachers should also always develop in accordance with the development of era to fulfill the needs of students.

ICT has brought many benefits to education, affecting many countries to implement ICT in learning (Andoh, 2015, p. 1), including learning in Vocational High Schools (SMK) in Indonesia. SMK is one of the secondary education level that specifically prepares its graduates to ready to work according to their area of expertise (Yogiyatno \& Sofyan, 2013, p. 392). There are various areas of vocational expertise in Indonesia, one of which is the area of business and management expertise. The area of business and management expertise is an area of expertise that develops professions of business and management professions including accounting skills programs. 
Accounting learning in SMK covers not only theory but also requires skill, practice, and real practice. The demand is in accordance with the objectives of the SMK is to produce graduates who are ready to work in accordance with the field of expertise. Therefore, in order to achieve these objectives, it is necessary that learning can provide students with a learning experience that is close to the actual field conditions.

The use of ICT in education is able to change the old paradigm of learning by displaying technology as a teaching tool to supporting the learning process (Admadja \& Marpanaji, 2016, p. 174). ICT makes it easier for students to search for information needed in learning (Menkhoff, Yian, Wah, \& Kee, 2011, p. 147). The use of ICT in learning, such as computer applications, enables an effective and efficient learning process in terms of time and material achievement (Himmah \& Triyono, 2014, p. 234). ICT can also be used to help improve the quality of learning and student learning outcomes. However, in fact the utilization of ICT in SMK has not been optimal (Pratiwi, Siswandari, \& Santosa, 2017, p. 77). This is because in the learning in SMK is still dominated by the use of textbooks. Teachers also still use lecture methods so that learning depends on the teacher's explanation. The facilities and infrastructure provided by the school are also quite adequate. Meanwhile, the curriculum requires independent and student-centred learning with the assistance of technology. It makes students feel saturated and passive during the learning so that they have difficulties understanding the material being taught.

Understanding is the ability of a person to understand something after it is known and remembered (Sudijono, 2006, p. 50). For optimal understanding, it is necessary to make conditions that support in learning. Student understanding can be imrpoved using innovative ICT-assisted learning (Butler \& Reddy, 2010 , p. 772). The use of ICT in learning can be utilized as learning media. The use of ICT as learning media can be in the form of Point Point slide file, pictures, animation, video, audio, simulation program, and others (Tellez, 2008, pp. 192-193). ICT-based learning media have proven to have potential and pedagogic value to improve the quality of learning (Marquez, Machuca, \& Lopez, 2010, p. 1396).
According to Zweekhorst \& Maas (2014, p. 16) ICT-based learning media can facilitate and improve the level of communication and interaction between students and between students and teachers. Students feel more involved in learning so that students also feel the understanding of the material increases so that the learning outcomes also increase.

The development of ICT in the world of education has also changed the students' attitudes in learning including in accounting learning in SMK. Multimedia is one of the varieties of ICT-based learning media. The multimedia used to facilitate learning can be defined as an integral combination of text, graphics, sound, animation, and video elements that are digitally processed through computers to deliver learning materials from learning resources to learners in which learners are able to actively control which elements appear and when the appearance of these elements (Yogiyanto \& Sofyan, 2013, p. 394). Multimedia is an appropriate tool and allows students to actively engage in learning and facilitate learning, and enable students to make decisions or take active action involving them in the learning process (Marquez, et al., 2012, p. 1402).

Multimedia has great potential as an effective learning medium used in areas of study that are difficult to visualize (Kulasekara, Jayatilleke, \& Coomaraswamy, 2008, p. 83). ICT-based learning by utilizing multimedia can be used as an easy-tounderstand learning media alternative for students so as to improve students' mindset thoroughly, sustainably and provide deep understanding as it bridges the gap between theory and practice. Multimedia can also improve student learning outcomes and improve interaction between students and teachers so that students will be more active and communicative during the learning process. Therefore, multimedia is expected to strengthen the strategy in accounting learning in SMK (Pratiwi, et al., 2017, p. 77). This is supported by the opinion of Sithole (2017, p. 1) stating that students' understanding in accounting subject can be improved by integrating texts and diagrams (multimedia).

Based on these conditions, students need learning that combines direct vis-a-vis learning and ICT-assisted learning (Weil \& Silva, 2014, p. 224). The utilization of ICT- 
based accounting multimedia (MAKSI) is expected to be an alternative medium of accounting learning to improve students' understanding. MAKSI is a combination of various learning media assisted by technology, information, and communication which together display information to convey accounting learning materials to students. The accounting learning material available on the MAKSI is a bank reconciliation. MAKSI is designed with an attractive look and includes material, simulated material work, and student learning evaluations packaged in animated video and games. Interesting media concepts, fun, and can provide a direct learning experience for students in accordance with the conditions of students and kebutuhsn learning media that students need.

Accounting material used in this research is bank reconciliation material taught to the eleventh-grade students of accounting department. Bank reconciliation is an analysis of the information and the amount that causes the cash balance reported in the current account to be different from the cash balance in the ledger, and aims to generate adjusted cash balances (Reeve, Warren, \& Dunchac (2009, p. 407). Students are required to understand the definition of bank reconciliation and the causes of bank reconciliation to recording and reporting procedures of bank reconciliation By studying this material is expected to be a provision for students in facing the world of work in the field of accounting and financial institutions. This material was chosen because based on the results of initial interviews with 60 elelventh-grade students of accounting department in SMK Negeri 1 Surabaya, $65 \%$ of them stated bank reconciliation material was a difficult material to understand. Therefore, this study aims to describe the utilization of ICT-based accounting multimedia (MAKSI) to impove students' understanding on bank reconciliation material in SMK.

\section{RESEARCH METHOD}

The type of this research is quantitative descriptive research with case study method. The research was conducted at SMK Negeri 1 Surabaya. SMK Negeri 1 Surabaya is one of the vocational school that has the competency of Accredited Accounting A and has a quality management system standardized ISO 9001:
2000. In addition, the curriculum used is the Kurikulum 2013 and the availability of facilities and infrastructure in SMK Negeri 1 Surabaya also support for the implementation ICT-based learning. The Kurikulum 2013 is designed to create student-centered learning that not only prioritizes knowledge development, but also student attitudes and skills. The Kurikulum 2013 also requires the use of ICT in the learning process to support studentoriented learning. In the Kurikulum 2013, financial accounting subjects are productive subjects taught during the six hours of lessons during the week that are held by eleventhgrade students and twelfth-grade students. One of the materials in it is a bank reconciliation material taught to students of eleventhgrade students of Accounting.

The subjects of this research were eleventh-grade students of accounting department who had learnt bank reconciliation material. The sample used was 40 students selected using simple random sampling technique because all students who were made into the population learnt the same material, the methods, learning media, and curriculum so that the population is considered homogeneous. The selected students were given preliminary tests before using MAKSI, then were given lessons by using MAKSI, and were given final tests to determine the increase in their understanding. The data were collected using the test technique so that quantitative data was obtained. In addition, observations and interviews were conducted to find out the students' opinions about the benefits of using MAKSI in learning.

The instrument used in this research was an essay test analysed quantitatively, and the observation sheet and interview sheet were analysed descriptively. The essay test is a test in the form of a written question whose answer is essay or long sentence (Purwanto, 2010, p. 35). Essay tests are chosen because these form tests are suitable for comprehensive knowledge, application and analysis so as to fit the characteristics of the bank's reconciliation materials. For the test scoring using the point method because the essay test used is an essay test with limited answers. An essay test with limited answers is an essay test that answers can be formulated specific answers guidelines (limited) so that it can be determined the score of each question 
(weighting). The use of essay tests in this study aims to reveal the students' understanding of the bank's reconciliation material.

The results obtained from the test were analysed by scoring on each indicator of the problem in accordance with the scoring guidelines that have been made. The score was then calculated using the percentages correction formula (Purwanto, 2010, p. 102). the score was then interpreted based on the interpretation criteria of student understanding in Table 1.

Table 1. The Interpretation Criteria of the Students' Understanding

\begin{tabular}{ccc}
\hline Assessment & Predicates & Critical Interpretation \\
\hline $0-30$ & E & Very Less Understanding \\
$31-55$ & D & Less Understanding \\
$56-65$ & C & Sufficient Understanding \\
$66-79$ & B & Good Understanding \\
$80-100$ & A & Very Good Understanding \\
\hline
\end{tabular}

\section{RESULTS AND DISCUSSIONS}

Efforts to improve students' understanding through the utilization of ICT-based accounting multimedia (MAKSI) showed satisfactory results. As many as $65 \%$ of the 40 students tested were able to exceed the minimum score (KKM) of accounting subjects by 75 after using MAKSI. Yet, before using MAKSI, all students had not been able to reach it. The essay test used as a test instru- ment consists of 4 questions concerning bank reconciliation material. The items were made based on the indicators of learning objectives to be achieved; they are: the definition and scope of bank reconciliation, the causes of bank reconciliation, the reasons for bank reconciliation, and the practice of bank reconciliation procedure implementation.

The results of the essay test score analysis showed the average understanding of students before using MAKSI is 52.18 with less category, while that after using MAKSI increases to 76.23 with good category. This shows that in general the use of MAKSI can improve students' understanding on bank reconciliation material. A more detailed explanation of the students' understanding of essay work on bank reconciliation materials for each item is as follows:

\section{The Definition and Scope of Bank Reconciliation}

The first item on the essay test given to the students relates to the understanding and scope of bank reconciliation. Students are asked to explain the meaning of bank reconciliation and the meaning of the bank statement. The maximum score that students get if they are able to answer the first question correctly is 10 . The students' understanding in answering this question indicator can be illustrated in Figure 1.

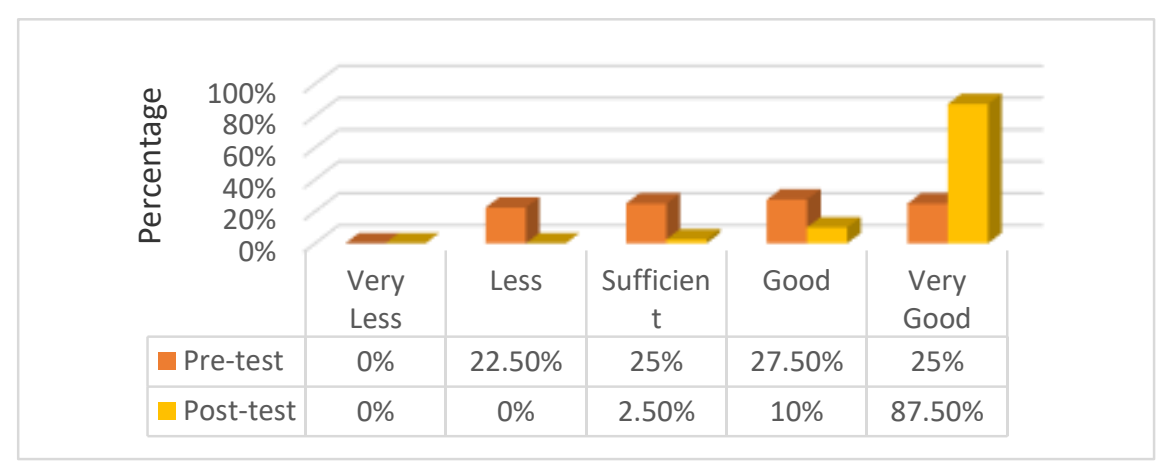

Figure 1. Student's Understanding on the First Question Indicator 
Based on the Figure 1, it appears that there is an increase in students' understanding of the indicator of definition and scope of bank reconciliation before and after using MAKSI. Before using MAKSI, the students have a very good understanding by only $25 \%$, good understanding category by $27.5 \%$, sufficient category by $25 \%$, and less category by $22.5 \%$. The results showed that some students did not yet have a good understanding of the definition and scope of bank reconciliation. This happened because they felt that the bank reconciliation material was unattractive so it was easily forgotten. Moreover, the media used were only in the form of textbooks so that they got bored and less understanding of this first indicator. However, some other students already had good understanding so as to describe the understanding and scope of bank reconciliation completely.

After using MAKSI, the percentage of the students' understanding increases to $87.5 \%$ in the category of very good understanding, $10 \%$ in good category, and $2.5 \%$ in sufficient category. The results show that after using MAKSI, the students' understanding about the definition and scope of bank reconciliation increases, even most of the students have a very good understanding. They felt that MAKSI is an interesting medium and helps them more easily memorize and understand the definition and scope of bank reconci- liation. Therefore, after using ICT-based accounting multimedia, they a complete understanding of the definition and scope of bank reconciliation.

\section{The Causes of Bank Reconciliation}

The second item on the essay test given to the student is related to the cause of the bank reconciliation. Students are asked to explain what factors are causing differences in cash balances between the company and the bank along with the sample of the transactions. The maximum score that students get if they are able to answer the second question correctly is 15 . The students' understanding in answering this question indicator can be illustrated in Figure 2.

Based on figure 2, it appears that before using MAKSI, the students had a poor understanding in answering questions related to the indicator of the causes of bank reconciliation. This is evident from the percentage of the students who have less understanding by $75 \%$ and the remaining $25 \%$ have very less understanding. This condition indicates that the student has not mastered what causes the happening of bank reconciliation so that less can describe the causes completely. They felt that the terms used in textbooks are difficult to understand so they were less able to interpret the terms.

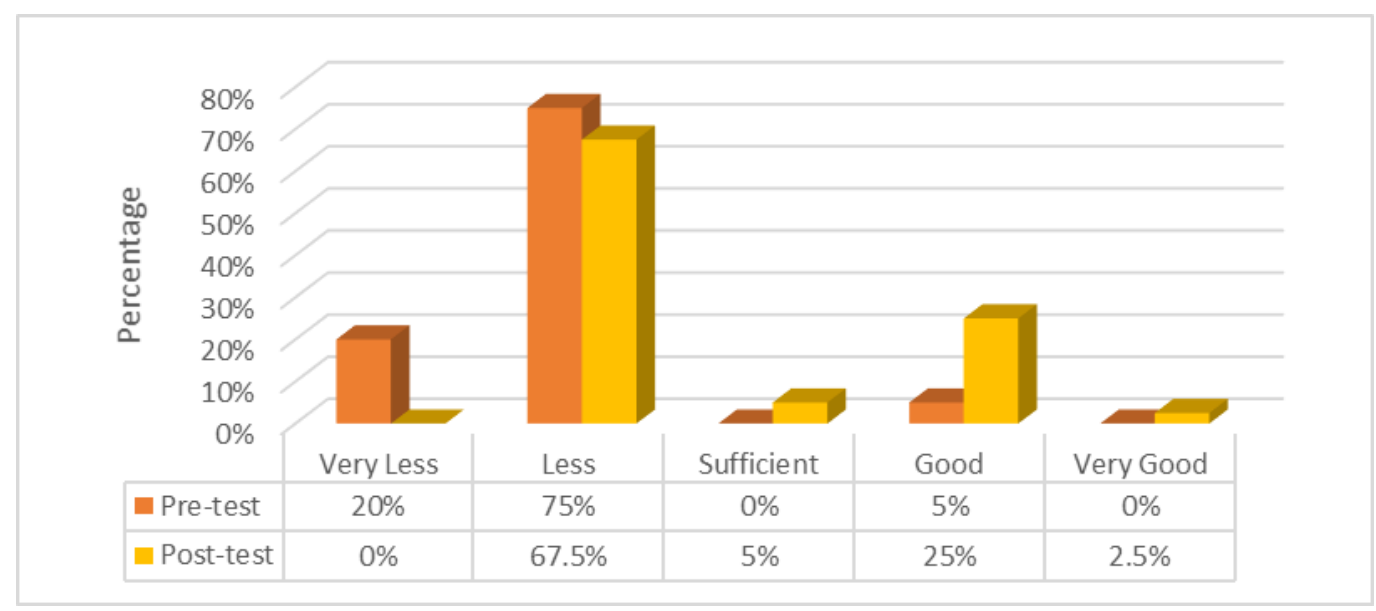

Figure 2. Student's Understanding on the Second Question Indicator 
After using MAKSI, the percentage of the students' understanding increases to $2.5 \%$ with very good understanding category, $25 \%$ with good understanding category, $5 \%$ with sufficient understanding category, and $67.5 \%$ with less understanding category. These results indicate an increase in students' understanding of the underlying causes of bank reconciliation after using ICT-based accounting multimedia although some students still have less understanding. Students have been able to describe the causes of bank reconciliation even though it is still simple so they can not get maximum score on this second question. Students felt that by using MAKSI, they can understand the causes of banl reconciliation more easily than by using textbooks.

\section{The Reasons for Bank Reconciliation}

The third item on the essay test given to the student is related to the reason for bank reconciliation. Students are asked to explain why the company is reconciling the bank to determine the amount of the company's cash balance. The maximum score that students get if they are able to answer the third question correctly is 10 . The students' understanding in answering this question indicator can be illustrated in Figure 3.
Based on Figure 3, it appears that there is an increase in the indicator of the reason for bank reconciliation. It can be seen from the percentage of the students' understanding before MAKSI by $5 \%$ with very less understanding category, $60 \%$ with less understanding category, $10 \%$ with sufficient understanding category, $10 \%$ with good understanding category, and $15 \%$ with very good understanding category. This is because the students felt that they have not been able to find the reasons why bank reconciliation is required because they are implied in the textbook. The students tend to memorize this material so that they have not been able to deduce and find the common thread on the material learned.

After using MAKSI, the percentage of the students' understanding increases to $15 \%$ with less understanding category, $15 \%$ with sufficient understanding category, $25 \%$ with good understanding category, and $45 \%$ with very good understanding category. These results show that after using ICT-based accounting multimedia, the students were able to answer the question completely because they have good understanding when compared to their understanding before using ICT-based accounting multimedia.

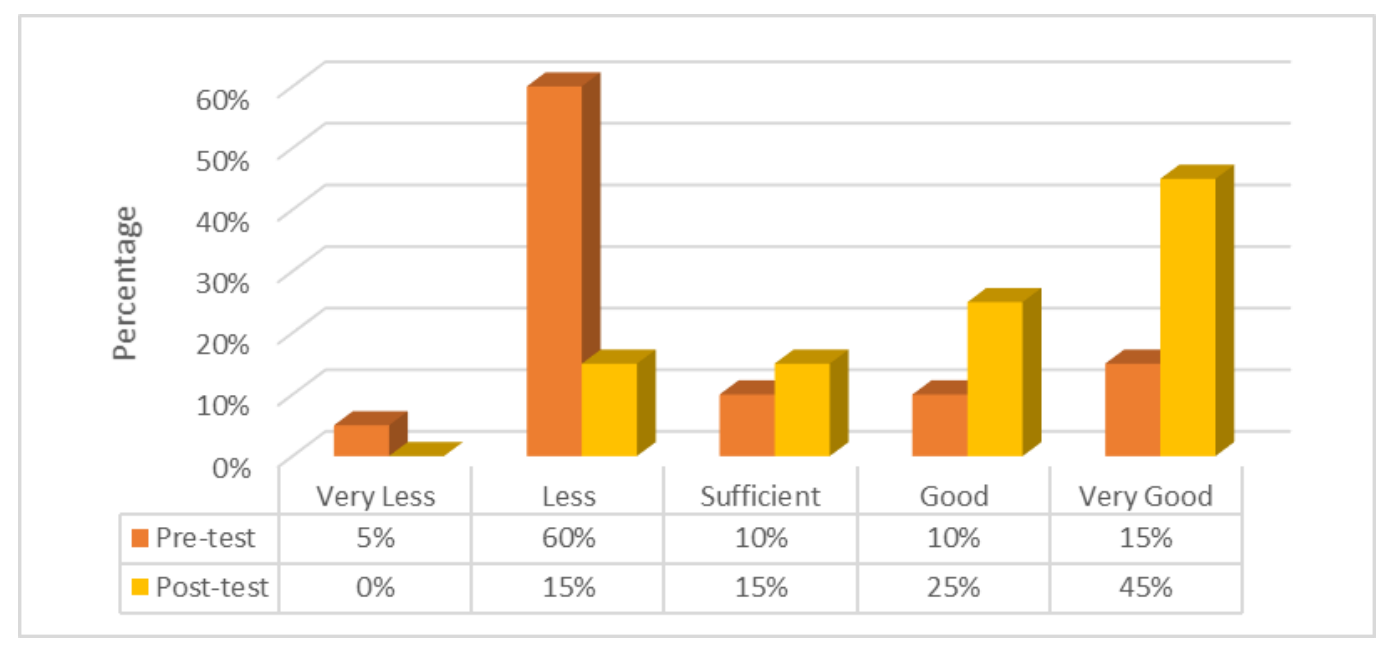

Figure 3. Student's Understanding on the Third Question Indicator 
This increase in understanding is because they have a clearer picture of bank reconciliation material, so they can find the bank reconciliation reasons for the company. The picture was obtained by the students from the illustration presented in the form of a learning video on one of the menus available on MAKSI.

\section{The Practice of Bank Reconciliation Procedure Implementation}

The fourth item on the essay test given to the students relates to the practice of bank reconciliation work. This last question consists of two instructions of practice on the case of transactions related to bank reconciliation. At the first instruction, the student is required to create a bank reconciliation report in the form of a reconciliation of the balance by the bank and the balance according to the company leads to the correct balance, as well as the form of balance reconciliation by bank leading to the balance of the company. The maximum score a student receives if able to answer this first instruction correctly is 50 . Then in the second instruction, the student is required to create a journal to be made by the company to adjust the cash balance based on the bank reconciliation report that has been made. The maximum score that students get if able to answer the second instruction correctly is 15 . Thus the total score of the four items of the essay test used is 100 . The students' understanding in answering this question indicator can be illustrated in Figure 4.
Based on Figure 4, the students' understanding on the indicator of the practice of bank reconciliation procedure implementation increases. Before using MAKSI the percentage of students include in the category of very less understanding is $2.5 \%$; the category of less understanding is $67.5 \%$; the category of sufficient understanding is $17.5 \%$; the good understanding category is $5 \%$; and the very good category is $7,5 \%$. This is because they did not understand the reasons why the bank reconciliation is required well so that they have difficulty in doing the practice of bank reconciliation.

After using MAKSI, their understanding increases to $15 \%$ with less understanding category, $5 \%$ with sufficient understanding category, $32.5 \%$ with good understanding category, and $47.5 \%$ with very good understanding category. These results indicate that after using ICT-based accounting multimedia, students' understanding of bank reconciliation procedure implementation increases so as to fully implement the practice of bank reconciliation. They were able to work on issues related to bank reconciliation arrangements in the form of bank reconciliation leading to the correct balance, and bank reconsideration leads to the balance of the company to arrange the journal needed to correct errors from the bank reconciliation. This is because students can work on a simulation of reconciliation in a more interesting way in the MAKSI application. Students felt that the learning was more fun so it was easier to understand the material.

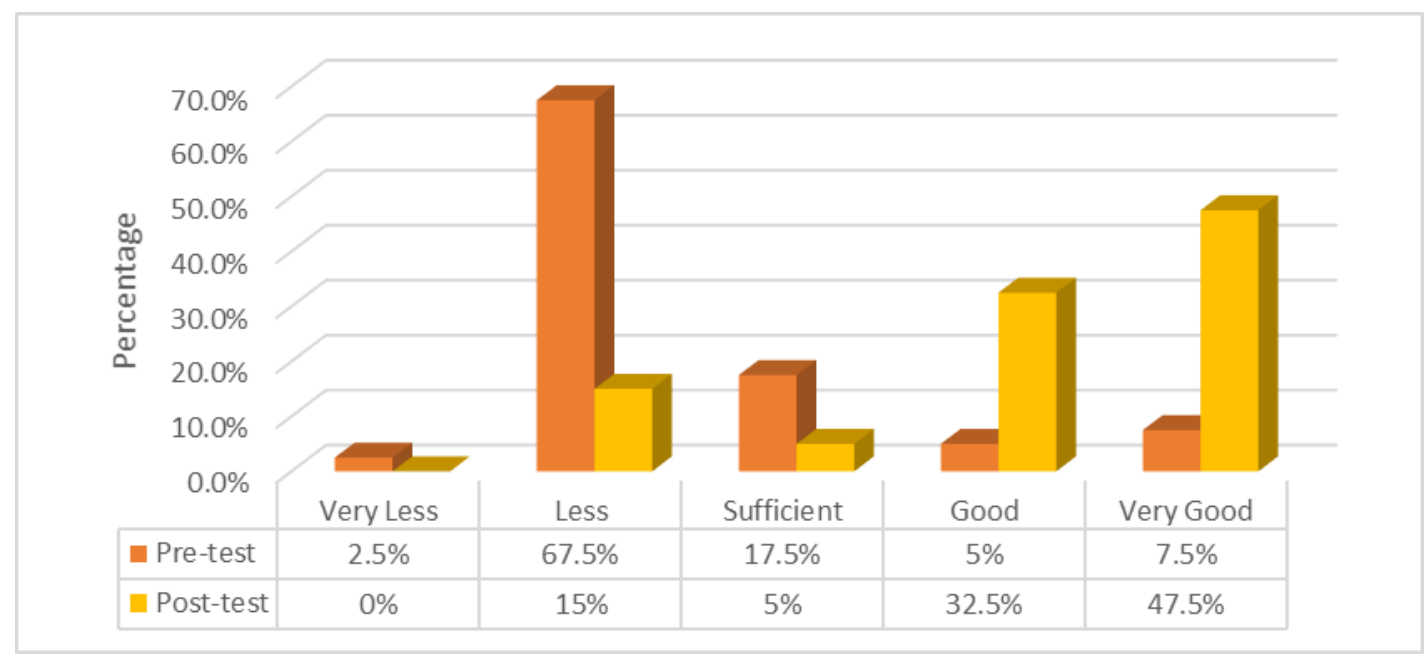

Figure 4. Student's Understanding on the Fourth Question Indicator 
From the overall results, it can be concluded that before using MAKSI, $62.5 \%$ of 40 students included in the category of having less understanding. Only 10\% of students include in the category of good understanding, while the remaining $27.5 \%$ include in the category of sufficient understanding. After learning using MAKSI, the category of the students who have good understanding increases to $40 \%$. Moreover, $40 \%$ of students include in the category of very good understanding. Those in the category of less understanding are only $7.5 \%$ of 40 students and the remaining $12.5 \%$ is in the category have sufficient understanding.

Students 'success in understanding a concept can be seen from the students' ability to name the examples of a concept, to name the characteristics of a concept, to choose and to distinguish between an example from and not from a concept, and to solve a problem related to the concept learned (Hamalik, 2003, p. 166). If the learning materials delivered by the teacher can be understood by the students, then the students can master each competence well so that the mastery of student competence can increase (Mariyati, 2012, p. 129). Increased mastery of student competence is a manifestation of the results of teaching activities conducted by teachers have been running well.

The use of MAKSI on bank reconciliation material can provide variations in accounting learning and make it easier for students to understand the material by providing a hands-on learning experience to make
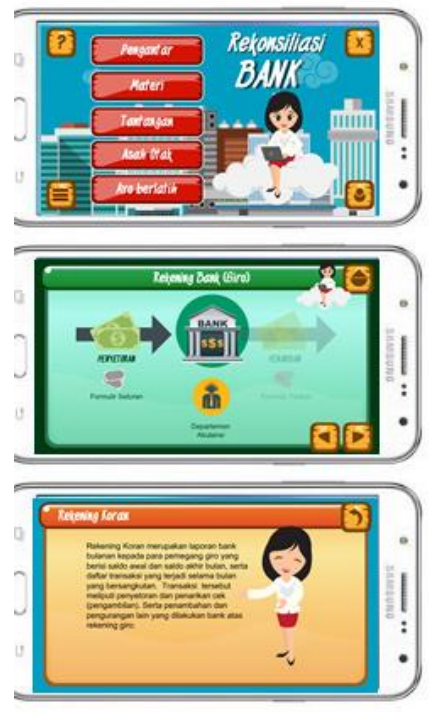

Figure 5. The Interface of MAKSI the students interested, active, and interactive so that their level of understanding increases. The increased understanding of the students is expected to facilitate teachers and students in achieving learning objectives. The benefits of using MAKSI as an ICT-based learning media in SMK on accounting skills program are also expected to familiarize teachers in the use of ICT in learning. Attempts to increase teachers' ability to learn and use ICT-based tools are needed because if teachers have mastered the use of ICT then teachers will feel comfortable to integrate ICT in the learning process (Destiana \& Soenarto, 2014, p. 296).

Thus, the effective use of MAKSI tested is used in accounting learning because it can improve students' understanding. This is because the use of MAKSI can create a fun learning and raises students' curiosity so that students are motivated to be active and learn independently in the classroom (Nickchen \& Mertsching, 2016, p. 482; Trieb, 2016, p. 310; Shittu \& Shittu, 2015, p. 191). Thus, the teacher can act as a facilitator in the learning task of assisting and directing students if having difficulty in learning the material. That learning conditions are in line with the demands of the Kurikulum 2013, which is student centered learning. In addition, MAKSI is also easy to use by students. Exciting displays like games and ease of media operation accessible on laptops/computers and smartphones through free downloading on Play Store make this media flexible to use. The MAKSI interface used in this study is presented in Figure 5.

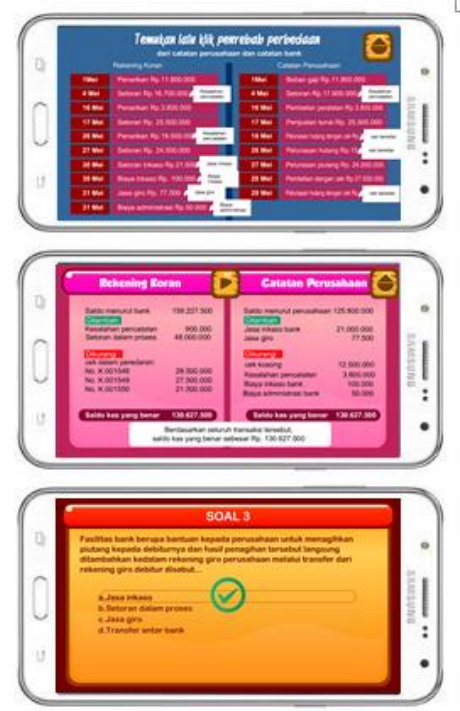




\section{CONCLUSIONS}

Based on the discussion, it can be concluded that the use of ICT-based accounting multimedia is proven to increase students' understanding. This is evidenced by the improvement of the students' ability to answer the questions and to solve the case of bank reconciliation practices. ICT-based accounting multimedia (MAKSI) on bank reconciliation materials can be complementary, alternative, and varied instructional media that can be used in Vocational High School (SMK) learning in Accounting skills programs. The utilization of MAKSI can create a fun learning and raise students' curiosity so that they are motivated to be active and learn independently in the classroom. Such learning conditions are in accordance with the demands of the curriculum, namely learning centred on student development (student-centred).

The headmaster as the manager and the person in charge of the implementation of learning in school are expected to maximize the facilities and infrastructure of the schools to support ICT-based learning process. Therefore, headmaster should motivate teachers to be able to develop innovative and creative learning through training and workshops. Then, teachers as the executor of learning activities should start habituating the use of ICT in learning according to the demands of the curriculum starting with the use of ICTbased accounting multimedia (MAKSI) on bank reconciliation material. The steps that teachers need to do in operating ICT-based multimedia accounting (MAKSI) as follows: (a) make sure school facilities and infrastructure support for the use of MAKSI, such as: computers/laptops, LCDs, and projectors for the application of classical learning; (b) make sure most students have an android based smartphone so students can install MAKSI apps to implement self-learning; (c) for the operation on the laptop/computer file application MAKSI must be duplicated (copy) first in the device to be used. MAKSI application file for operation on laptop/computer using .swf format so it must be available Adobe Flash application; (d) for smartphone operation download MAKSI in Play Store with keyword: bank reconciliation; (e) install the MAKSI app on your computer/laptop and smartphone to start operating the app; (f)
MAKSI is ready for use in accounting learning.

Thus, it is expected that MAKSI can help sustainable accounting learning in Vocational High School (SMK) to increase students' understanding.

\section{Acknowledgements}

This article is based on the research conducted by the authors financed by Lembaga Pengelola Dana Pendidikan (LPDP) of the Republic of Indonesia. The author also gratefully acknowledge the helpful comments and suggestions of the reviewers, which have improved the article.

\section{REFERENCES}

Admadja, I. P. \& Marpanaji, E. (2016). Pengembangan multimedia pembelajaran praktik individu instrumen pokok dasar siswa SMK di bidang keahlian karawitan. Jurnal Pendidikan Vokasi, 6(2). Retrieved from https://journal.uny.ac.id/index.php/jpv/ar ticle/view/8107

Andoh, C. B. (2015). ICT usage in Ghanaian secondary schools: teacher's perspectives. The International Journal of Information and Learning Technology, 32(5), 1-15.

Butler, M. J. R., \& Reddy, P. (2010). Developing critical understanding in HRM students: using innovatif teaching methods to encourage deep approaches to study. Journal of Europan Industrial Training, 34(89), 772-789.

Cajkler, W. \& Wood, P. (2016). Mentors and student-teachers "lesson studying" in initial teacher education. International Journal for Lesson and Learning Studies, 5(2), 84-98.

Destiana, B. \& Soenarto. (2014). Faktor determinan pemanfaatan TIK dan pengaruhnya terhadap kinerja guru SMK di Kabupaten Gunungkidul. Jurnal Pendidikan Vokasi, 4(3), 285-299.

Retrieved from https://journal.uny.ac.id/index.php/jpv/ar ticle/view/2555/2109

Dimyati \& Mudjiono. (2010). Belajar dan 
pembelajaran. Jakarta: PT Rineka Cipta.

Hamalik, O. (2003). Metode belajar dan kesulitan-kesulitan belajar. Bandung: Remaja Karya.

Himmah, L. N. \& Triyono, M. B. (2014). pengaruh pembelajaran berbantuan media berbasis komputer terhadap kompetensi siswa membuat pola di SMKN 6 Yogyakarta. Jurnal Pendidikan Vokasi, 4(2), 232-245. Retrieved from https://journal.uny.ac.id/index.php/jpv/ar ticle/view/2549

Kulasekara, G. U., Jayatilleke, B. G., \& Coomaraswamy, U. (2008). Designing interface for interactive multimedia: learner perception on the design features. Asian Association of Open Universities Journal, 3(2), 83-98.

Lindberg, O. J., Olofsson, A. D., \& Fransson, G. (2017). Same but different? An examination of Swedish upper secondary school teachers' and students' views and use of ICT in education. International Journal of Information and Learning Technology, 34(2), 122-132. https://doi.org/10.1108/IJILT-09-20160043

Marquez, F.J.A., Machuca, J.A.D., \& Lopez, G.M. (2012). Interactive learning in operation management higher education: software design and experimental evaluation. International Journal of Operation \& Production Management, 32(2), 1395-1426.

Mariyati, D. (2012). Peningkatan motivasi dan pemahaman siswa SMKN 5 Banjarmasin terhadap dasar teknik digital dengan media simulasi electronic workbench (EWB). Jurnal Pendidikan Vokasi, 2(1) 127-142. Retrieved from https://journal.uny.ac.id/index.php/jpv/ar ticle/view/1023

Menkhoff, T., Yian, T. T., Wah, C. Y., \& Kee, W. Y. (2011). Engaging knowledge management learners through web-based ICT: an empirical study. The Journal of Information and Knowledge Management Systems, 41(2), 132-151.

Nickchen, D. \& Mertsching, B. (2016). Combining mathematical revision courses with hands-on approaches for engineering education using web-based interactive multimedia applications. Procedia-Social and Behavioral Sciences, 228, 482-488.

Pratiwi, V., Siswandari, \& Santosa, D. (2017). Interactive multimedia based ICT to enchance accounting learning strategy in vocational school. Proceeding Advances in Social Science, Education and Humanities Research, 116, 75-78.

Purwanto, M. G. (2010). Prinsip-prinsip dan teknik evaluasi pengajaran. Bandung: PT. Remaja Rosdakarya.

Reeve, J. M., Warren, C. S., \& Dunchac, J. E. (2009). Pengantar akuntansi adaptasi Indonesia. Jakarta: Salemba Empat.

Sanjaya, W. (2013). Strategi pembelajaran berorientasi standar proses pendidikan. Jakarta: Kencana.

Saputra, W. \& Purnama, B. E. (2012). Pengembangan multimedia pembelajaran interaktif untuk mata kuliah organisasi komputer. Journal Speed, 4(2), 60-67.

Scott, B. \& Cong, C. (2010). Evaluating course design principles for multimedia learning material. Campus-Wide Information Systems, 27(5), 280-292.

Shittu, N. A. A. \& Shittu, A. J. K. (2015). Assesing the impact of ICT deployment in teaching and learning in higher education: using ict impact assesment model. Journal of Applied Research in Higher Education, 7(2), 180-193.

Sithole, S. T. M. (2017). Enhancing students understanding of introductory accounting by integrating splitattention instructional material. Accounting Research Journal, 30(3), 1-15.

Sudijono, A. (2006). Pengantar evaluasi pendidikan. Jakarta: PT Raja Grafindo Persada.

Tellez, A. G. (2008). Authoring multimedia learning material using open standards and free software. Interactive Technology and Smart Education, 4(4), 192-199.

Trieb, C. A. (2016). Application of learning 
technologies to promote holistic thinking and consensus building in global studies. The International Journal of Information and Learning Technology, 33(5), 300314.

Wankel, L. A. \& Blessinger, P. (2015). Inventive Approaches in Higher Education: An Introduction to Using Multimedia Technologies. Cutting-edge Technologies in Higher Education, 6, 316.

Weil, S. \& Silva, T. D. (2014). Blended learning in accounting: a New Zealand case. Meditari Accountancy Research,
22(2), 224-244.

Yogiyatno, W. \& Sofyan, H. (2013). Pengembangan multimedia interaktif kompetensi dasar mengoperasikan software basis data untuk SMK Negeri 1 Seyegan. Jurnal Pendidikan Vokasi, 3(3), 391-404. Retrieved from https://journal.uny.ac.id/index.php/jpv/ar ticle/view/1851

Zweekhorst, M. B. M. \& Maas, J. (2014). ICT in higher education: students perceive increased engagement. Journal of Applied Research in Higher Education, 7(1), 2-18. 